\title{
Gastro-Tourism as Destination Branding in Emerging Markets.
}

\begin{abstract}
Food related gastro-tourism refers to the pursuit of appealing, authentic, memorable culinary experiences of all kinds, while traveling internationally, regionally or even locally. For gastrotourists, food is the focus and the motivation for the travel. In developed countries the gastrotourism business is booming and has become one of the most dynamic and creative segments of tourism, attracting billions of tourists worldwide. Destination brand strategy is defined as “a plan for defining the most realistic, most competitive, and most compelling strategic reason for the country, region, or city” (Anholt, 2004). Gastro-Tourism can be a driver of destination choice, especially for emerging markets. This paper defines Gastro Destination Branding, and introduces and discusses a conceptual Gastro-Tourism Destination Identity process model to assist various towns, cities, regions and countries to maximize the potential of the growing gastro-tourism market through effective use of destination branding.
\end{abstract}

\section{Keywords}

Gastro destination branding, gastro-tourism, emerging markets, culinary tourism, place branding 


\section{Introduction and Literature Review}

The literature review begins with definitions and subcategories of tourism, and then describes overlaps and terminology confusion specific to food-related tourism. Place / Destination Branding is introduced and gastro-tourism destinations where food and food experiences become the destination are examined. The possibilities of branding Food Destinations within emerging markets are acknowledged.

\section{Definitions and Subcategories of Tourism}

The term tourism generally refers to the act of staying outside of a normal living-working environment for between one day and one year for recreational, leisure or business reasons (Wikipedia). Tourism is further broken down into domestic tourism (people traveling within their own country) and international tourism (people traveling across country borders or overseas). Within these two distinct categories exist multiple subcategories of specialized tourist divisions that include but are not limited to the types listed in Table 1 below

\section{Table 1 Specialized Tourism Categories}

\begin{tabular}{|c|c|}
\hline Tourism Categories & Explanation \\
\hline Adventure or Extreme Tourism & To remote, exotic, sometimes hostile destinations; outside of comfort zones \\
\hline Agritourism & $\begin{array}{l}\text { Travel to dude ranches, country farms, country inns and rural bed \& } \\
\text { breakfasts. Gastro-tourism is linked }\end{array}$ \\
\hline Backpacking - Wilderness & Hiking and camping in the backcountry \\
\hline Backpacking -Travel & $\begin{array}{l}\text { Low-cost, usually international , using public transportation, staying in } \\
\text { hostels }\end{array}$ \\
\hline Cultural or Heritage Tourism & $\begin{array}{l}\text { Lifestyle, art, architecture, religion, cuisine, rituals. Gastro-tourism is } \\
\text { considered a subset }\end{array}$ \\
\hline $\begin{array}{l}\text { Dark or War Tourism } \\
\text { (also Black or Grief Tourism) }\end{array}$ & $\begin{array}{l}\text { Sites associated with: suffering and death, castles, battlefields, natural \& } \\
\text { manmade disaster areas, prisons and dungeons, ghost site-ings }\end{array}$ \\
\hline Disaster Tourism & Visiting areas affected by floods, hurricanes, volcanoes, etc. \\
\hline Eco Tourism & Small-scale, low-impact travel to fragile, untouched and protected areas \\
\hline Educational Tourism & Student exchange programs, internships abroad and study tours \\
\hline $\begin{array}{l}\text { Gastronomic, Gastro or Culinary Tourism } \\
\text { (includes, wine, beer \& gourmet tourism) } \\
\text { (linked to cultural and agritourism) }\end{array}$ & $\begin{array}{l}\text { Intentional pursuit of appealing, authentic, memorable culinary experiences } \\
\text { of all kinds, while traveling internationally, regionally or even locally. }\end{array}$ \\
\hline Genealogical Tourism & Concerned with researching personal familial lineage; linked to heritage \\
\hline Geo Tourism & Geographic character enhancement linked with Ecotourism \\
\hline GPS or Off-Trail Hiking & Relies on maps, compasses or GPS units; scavenger-style games \\
\hline Medical Tourism & $\begin{array}{l}\text { Leaving home area to obtain healthcare, often surgical procedures; or for the } \\
\text { delivery of healthcare }\end{array}$ \\
\hline Nautical Tourism & $\begin{array}{l}\text { Traveling to port(s) by boat, often living on boats; subset- cruise ship } \\
\text { excursions }\end{array}$ \\
\hline Pop Culture Tourism & $\begin{array}{l}\text { Locations featured in books, TV, current events, film, music, and other forms } \\
\text { of entertainment }\end{array}$ \\
\hline Religious Faith Tourism & Visiting holy sites for fellowship, missionary, healing or pilgrimage \\
\hline Space Tourism & Trips into space --Russian space agency \\
\hline Sports Tourism & Traveling to Sporting events, clinics, camps outside living or working areas \\
\hline
\end{tabular}




\begin{tabular}{|l|l|}
\hline Sustainable Tourism & $\begin{array}{l}\text { Sustaining a culture's population, employment, and positive local experiences } \\
\text { for residents and tourists }\end{array}$ \\
\hline Volunteerism & $\begin{array}{l}\text { Traveling for the purpose of charitable work, organized or sponsored by non- } \\
\text { profit or charitable groups }\end{array}$ \\
\hline Wildlife Tourism & Observation of wild animals in tier natural habitats \\
\hline
\end{tabular}

\section{Overlaps and Terminology Confusion Regarding Food-Related Tourism}

Food related tourism refers to trips made to destinations where local food and beverages are the main motivating factors for all or part of the travel. In its broadest sense, it is the pursuit of appealing, authentic, memorable culinary experiences of all kinds, while traveling internationally, regionally or even locally. The nature and quality of the food related experience is what matters the most. As table 1 above indicates, this specialized tourist niche is often referred to as: Culinary Tourism, Gastronomy or Gastronomic Tourism, the abbreviated and hyphenated Gastro-tourism, and the more generic Food Tourism that seems to be preferred in the USA. Lesser-used or specialized labels heard predominately in the higher end tourist markets include: Tasting Tourism, Gourmet Tourism, Cuisine Tourism, Food \& Wine Tourism, Wine Tourism, Beer Tourism, Spa Cuisine, and possibly other product or region-specific terms or destination brands. The definition originally proposed by Hall et al, (2003) used words and phrases such as experiential trip, gastronomic regions, recreational or entertainment purposes, visits to primary and secondary producers of food, gastronomic festivals, food fairs, events, farmers' markets, cooking shows, demonstrations, tastings of quality food products, and activities related to particular lifestyles and cultures. Gastronomy is an understanding of various social cultures, historical components, literature, philosophy, economic status, religions and others aspects, in which food is the core subject. Gastronomy products can refer not just to food and beverages but also to food-related activities pertaining to culture and heritage (Zahari et al.,2009).

Food and travel blogs, researchers, industry practitioners, and self proclaimed "foodies" use the terms Culinary Tourism and Gastronomic or Gastro-tourism somewhat interchangeably. As opposed to mass tourism (mass production and consumption), niche tourism [such as gastronomic tourism] deals with the study, participation and experiences within a locational 
region, and is part of the adaptation from a services economy to an experience economy (Hall \& Weiler, 1992; Goeldner et al, 2000; Pine and Gilmore, 1999). Narrowly defined, Gastronomic Tourism is a form of niche tourism motivated by food and/or drink (Hall \& Mitchell, 2005 Kivela and Croth, 2006, Sims, 2009)

The term "culinary tourism" was defined as an intentional exploratory participation in the foodways of someone considered an 'Other'; “an exploratory relationship with the edible world... ....whether you go to food or food comes to you, the nature of the encounter is what defines a food experience as culinary tourism” (Long, 1998, p xi). The International Culinary Tourism Association (ICTA) defines it as "the pursuit of unique and memorable eating and drinking experiences," while the UN World Tourism Organization consistently refers to this tourist niche as gastronomic tourism or gastronomy, and defines it as "gastronomic tourism applies to tourists and visitors who plan their trips partially or totally in order to taste the cuisine of the place or to carry out activities related to gastronomy” (UNWTO 2012, p.7).

It is widely accepted that the scholarship relevant to culinary tourism comes primarily from three fields: Anthology of Tourism, Folklore, and Food Studies and that these fields also very often overlap (Long, 2004). Theories are put into actions via festivals, public displays, presentations, new restaurant development, nutritional guidelines, etc. "The cross discipline approach makes a survey of [culinary tourism] literature "quite unwieldy" (Long, 2004, p.2). Studies related to food tourism have been largely limited to areas such as food safety, hygiene issues, analyses of food and wine festivals, supply issues, food production, food in tourism and cross-promotion of tourism in regional or national cuisines (Hall et al,. 2003).

Further research on Gastro Tourism addresses encounters with gastronomic system different from our own (Long, 2004); gastronomic learning (Smith \& Xiao, 2008); including familiar food to tourist in foreign milieus (Wight, 2008); engagement with and affect on all five senses (Cook et al, 2002); emotions generated by smell (Lindstrom, 2005); increased benefits and competitiveness via linkage to non-gastronomic tourism (Henderson, 2009); a major motivation for travel (Fox, 2007; Hall \& Mitchell, 2005; Wolf, 2002). Gordin (2009) further stratify gastro tourism into types, and elaborate on the gastronomic brand process. 


\section{Gastro Tourists}

In developed countries the gastro-tourism business is booming and has become one of the most dynamic and creative segments of tourism, attracting billions of tourists worldwide. Foodies flock to France, Italy and Spain to experience the culture and the people through traditional foods and local beverages. In a recent survey (UNWTO, p12) 88.2\% of member respondents indicated "gastronomy is a strategic element in defining the brand and image of their destination, yet only 67.6\% agreed that their country has its own gastronomic brand.” Further, gastro tourism 'products' offered involved food events (79\%), gastronomic routes and cooking classes (62\%) and visits to markets and producers (53\%). Ageing population and changing life styles have driven demand for food tourism opportunities, with populations that provide growing markets for food tourism often categorized as: DINKS: (Dual Income No Kids): SINKS (Single Income No Kids); Empty Nesters (parents whose children have left home): Baby Boomers (members of the baby boom generation in the 1950s); and Divorcees (abouTourism, 2012). A study by ICTA which focused on the behavior of Americans, found them to be comparable to research performed on culinary tourists in other countries, notably Canada, Australia, Switzerland and the United Kingdom: “Culinary travelers are similar in demographic and psychographic profiles in almost every country for which studies exist” (ICTA, 2007, p.3). The ICTA study referenced the following significant findings regarding culinary travelers: 1) They span all age groups; 2)They span both genders, in all ethnic groups; 3)They tend to be better educated; 4)They span various income levels.

Over 33\% of the money spent by tourists is dedicated to food (Quan and Wang, 2004); food and food-related events are a key source of tourism (Hjalager and Richards, 2002; Rao, 2001), and food is becoming an essential component in destination choice motivation (Hall et al 2003) In a recent survey (UNWTO, p12) 88.2\% of member respondents indicated "gastronomy is a strategic element in defining the brand and image of their destination, yet only $67.6 \%$ agreed that their country has its own gastronomic brand.” Further, gastro tourism 'products’ offered involved food events (79\%), gastronomic routes and cooking classes (62\%) and visits to markets and producers (53\%). A description of a serious gastro-tourist follows. 


\section{Motivation for Gastro-Tourism}

Various definitions, factors, and models for tourist motivation have been suggested, based upon the value and needs of consumers: tourist motivation definition (Pearce et al, 1998); factors of motivation (John \& Susan, 1999; Lee and Pearce, 2003; Mannell and Iso-Ahola, 1987; Pearce \& Lee, 2005); type and destination (Prebensen, 2007); measurment (Beard \& Ragheb, 1983; Kim \& Jogaratnam, 2002; Kozak, 2002); and motivations and destination choice (Moscardo et al, 1995). While interest in the development of food tourism has increased (Kivela and Crotts, 2006), little research exists on "culiniary, gourmet, and gastronomy tours motivation” (Kim et al 2010 p60). Food consumption itself remains the "peak" experience which motivates destination travel (Kay, 2003).

Tikkanen (2007) identified five distinct Maslow-ian motivations with respect to culinary travelers: 1) food itself is viewed as an attraction, 2) foodstuffs are products that culinary tourists consume and purchase, 3) food experiences are valued and sought, 4) food is viewed and valued as a cultural phenomenon, and 5) linkages between tourism and food production are sought and valued. She contends that specific individual needs of the food tourist constitute the main motivations for culinary tourism (figure 1 below).

Figure 1: Sectors of Food Tourism classified by Maslow's hierarchy of needs

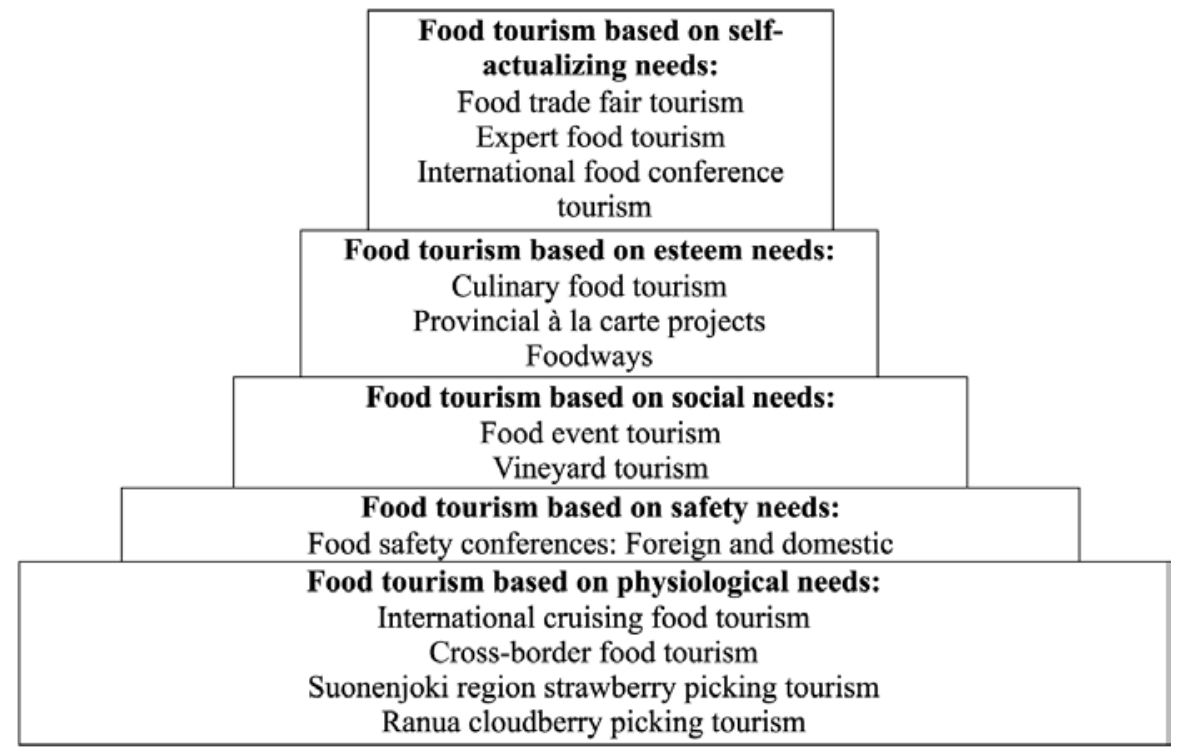


Food Tourists are motivated by interesting educational enriching hands-on-experiences. For gastro-tourists, food is the focus and the motivation for the travel.

\section{Place/Destination Branding}

There is a growing body of practice and research around place or destination branding. Place brand strategy is defined as "a plan for defining the most realistic, most competitive, and most compelling strategic reason for the country, region, or city; this vision then has to be fulfilled and communicated" (Anholt, 2004). Recurring themes within the various disciplines that discuss place branding include: comparisons between branding a product/service and destinations/cities (Cai, 2002; Gnoth, 2002; Kavaratzis and Ashworth, 2005; Parkerson and Saunders, 2005); comparisons between corporate branding and city brands (Kavaratzis, 2004; Olins, 2003; Trueman et al. 2004) and similarity to corporate umbrella branding (Gnoth, 2002; Papadopolos and Heslop, 2002); impressions between place branding and (re)positioning (Gilmore, 2002); image building and reconstruction (Curtis, 2001; Hall, 2004); the importance of unique identity and use of branding elements (Cai, 2002; Morgan et al. 2004); and, the role of emotional links with consumers (Gilmore, 2002; Hall, 2004).

Previous research has generally been specific to the individual aspects of the place branding process, and often based on specific case study contexts and, as such cannot easily be applied by practitioners. An interesting meta-model of the place-branding process was offered by Hanna and Rowley (2010). Their theoretical model of SPBM incorporates six broader place branding process models which together serves as a starting point: the relational network brand (Hankinson, 2004); city image communication (Kavaratzis, 2004); a model of destination branding (Cai, 2002), destination branding process (Laws, 2002); the 7A destination branding model (Baker, 2007); and city brand management (Gaggiotti et al., 2008).

Destination Branding involves the establishment and maintenance of an identity of the destination brand - places where tourists visit be it countries, regions, or cities - and are a key element involved with tourism (de Chernatory, 2010; Morgan et al, 2004). Konecnik (2002) categorizes a destination brand as a collection of products and services. A destination brand identity includes six to twelve dimensions (Aaker \& Joachimsthaler, 2000) involving 
experiential, symbolic and functional benefits (Keller, 1993). The destination brand must be authentic, and "organic and self-developing” (Olins, 2007). Indeed, in terms of nation branding every destination now competes for position with all other destinations (Anholt, 2007).

While destination branding offers the opportunity to counter the problem of place substitutability, there are a number of challenges that must be addressed when branding places.

Destination Branding involves a wide variety of stakeholders; volatile external environment; potentially difficult heritage issues; and budgetary pressures (Balakrishvan, 2009, Morgan et al, 2004; Pike, 2005). Other challenges include the multidimensionality of the place (Marzano and Scott, 2005), politics (Gilmore, 2002; Hankinson, 2004; Parkerson and Saunders, 2005; Pike, 2005), funding (Palmer, 2001 in: Morgan et al. 2002), the external environment (Morgan et al. 2004) and creating differentiation (Morgan $e t$ al. 2002). As a relatively new field of study, there remains a lack of empirical research on place branding (Caldwell and Freire, 2004). Since the motivations for eating particular foods are complex, varied and personal and what a gastro tourist considers memorable can vary drastically from one to another, the geographic location appears to be secondary. Food remains the star attraction, actually becoming the destination. The place or location is just the vehicle, or the backdrop for experiencing food in meaningful ways.

\section{Gastronomy as a Driver of Destination Branding}

A national survey done in partnership with the Travel Industry Association (TIA), Gourmet (the magazine) and the World Food Travel Association (WFTA) revealed that 27 million American Travelers (17\%) engaged in culinary or wine-related activities while traveling. On average they spent \$1,194 per trip with over 36\% (\$425) going towards food-related activities. The segment that the survey labeled "deliberate" food travelers, where culinary activities were the key reasons for the trip, spent on average $\$ 77$ more for the entire trip, but $50 \%$ of that total (\$593) was spent on food-related activates. Surprisingly, those travelers identified as wine travelers spent less on overage per trip (\$950), but did spend the same 36\% (\$339) on wine-related activities (WFTA, 2011). According to the Barcelona Field Studies Centre (2012), increases in food tourism are driven by five trends: 1) Trading Up: consumers spend a higher portion of their income on discretionary purchases when the product/experience is aspiration and down when it is only 
function; 2) Demographic and Household Changes: an aging population and lifestyle changes have driven demand for increased eating out and food tourism opportunities; 3) Rejection of 'MacDonaldisation': tourists reject low cost mass-produced foods that are perceived as bland and lacking individuality, searching out instead local, fresh, cuisine that reflects authenticity of the destination; 4) Growth of The Multi-Cultural Consumer: immigration, globalization, the internet, have spurred a relentless growth in international tourism; and 5) The Celebrity Chef and Media: the niche of food programs, TV channels and magazines have created food celebrities and experts to emulate.

\section{Gastro-Tourism in Emerging Markets}

With minimal infrastructure, a little organization, a bit of local hospitality, and targeted marketing, emerging markets in underdeveloped countries as well as underdeveloped pockets in developed nations can become gastro tourism destinations for travelers who yearn for intimate cultural immersion through food adventures. The factors to consider are shown in the Gastro Tourism Destination Identity Process Model below (figure 2).

Figure 2: Gastro-Tourism Destination Identity Process Model

\section{Gastro-tourism Destination Identity}

\begin{tabular}{c|c|c|c|c}
$\begin{array}{c}\text { Examine } \\
\text { Infrastructure }\end{array}$ & $\begin{array}{c}\text { Identify } \\
\text { Existing } \\
\text { Resources } \\
\text { FOOD }\end{array}$ & $\begin{array}{c}\text { Create } \\
\text { Destiination } \\
\text { Identities }\end{array}$ & $\begin{array}{c}\text { Market \& } \\
\text { Promote }\end{array}$ & Evaluate \\
RISKS & $\begin{array}{c}\text { PEOPLE } \\
\text { BENEFITS }\end{array}$ & PURVEYORS & IMPLEMENT & ONGOING \\
\hline
\end{tabular}

\section{Infrastructure}

The research seems encouraging that new markets in emerging nations or less affluent pockets within more dominate markets can capitalize on this ever growing gastro-tourism niche to provide economic, social and cultural benefits. By utilizing existing food resources and local 
experts a gastro-tourist program can be launched, even in remote parts of the world, provided that key infrastructure exists. Gastro tourism is appreciated not only for its own sake but also for its ability to generate rural development. "Gastronomic tourism is helping to increase rural revenue sources and improve income levels and employment of local labour, especially women (Barcelona Field Studies Centre, 2012). Countries as well as independent purveyors have found start-up risks to be minimal, provided three basic infrastructure elements are available, viable and enforced: 1) If a destination offers clean water, healthy food handling and sanitation practices; 2) can safely transport people to and from various purveyors; and 3) has the means to articulate and advertise a message. Figure 3 below depicts this basic infrastructure demand.

\section{Figure 3}
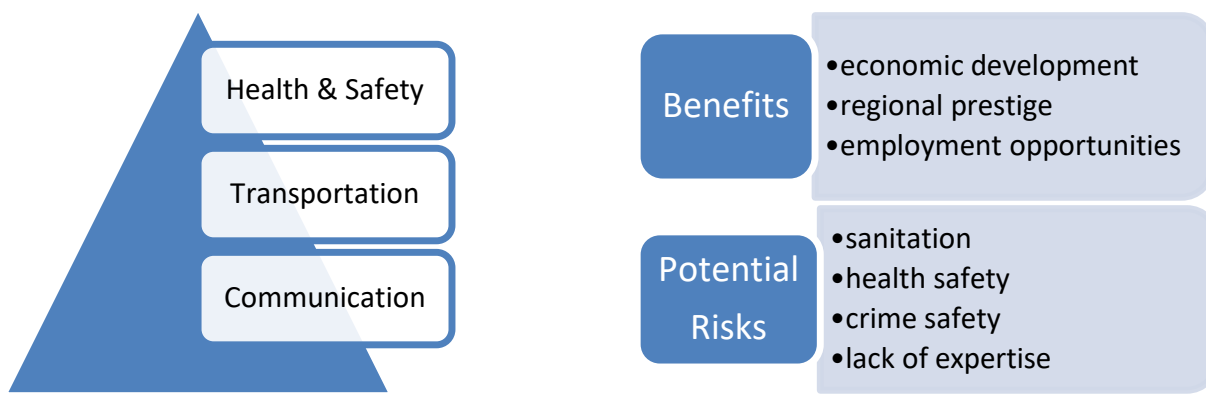

\section{Resource Identification}

The way a country, a region or even a local village or neighborhood gathers, prepares and serves food defines it's food tourism potential. The best gastro-gathering events stem from resources and products that are uniquely local, traditional, and are prepared and consumed by the locals. Sharing culinary flavors and styles teaches world travelers about people in other parts of the world or city in ways that geographical books, politics or tours of museums and landmarks can never fully do. Communities can easily identify their town experts and village matrons who might be eager to host gatherings for strangers willing to pay a fee to learn from them about foods and practices that already exist. Emerging markets should look at the resources that 
already exist in their neighborhoods, villages, towns, communities, cities and countries. Communities can begin by looking at local foods, festivals and harvesting seasons such as: Hairy Crab Season in Shanghai; China’s Cold Food Festival; LaMancha’s Saffron Harvest. If an area can identify at least six purveyors (hosts) with interesting food-related opportunities who are willing to loosely organize and continuously communicate, then gastro tourism becomes possible. The diagram below (figure 4) depicts this stage of the process.

\section{Figure 4}

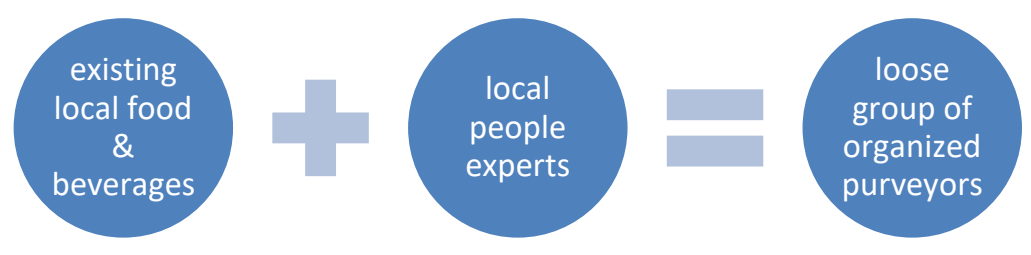

\section{Destination Identity}

Once a minimum of six experiences and hosts are identified, a 'trail' or schedule can be created that suits all purveyors and potential tourists. How a local group decides to brand their local food and food-related experiences is unique and highly individual. They can create food trails so tourists can taste similar or uniquely different foods and preparations; they can include kitchen gardens, cookery lessons in Mama's kitchens, dining on the docks, or bike tours through city streets. Regardless of the unique components, any loosely formed group of purveyors who wishes to advertise their gastro-possibilities to outsiders should agree upon brand promise: What is being promised to the gastro-tourists that visit? This promise becomes the guiding force in the actual creation of the events and experiences as well as in all marketing materials and messages regarding the gastro-tourism group. So, what exactly is being promised? Memorable local foodrelated experiences are a must. But, a community can also offer, fun, warmth, a glimpses into unique cultures, customs, rituals, hands-on cooking, and expert lectures and demonstrations. What each community is able and willing to promise will be unique.

Following are examples of two existing food-tourism initiatives. 1) The Global Hansik Initiative (GHI) was created and launched in 2008 to popularize Korean food by focusing on the health 
benefits and uniqueness of Korean cuisine both in Korea and around the world (MIFAFF, 2008). In this instance Korean Food itself becomes the "destination." 2) The Tourism Bureau of Taiwan has launched its new global campaign slogan:“Taiwan — The Heart of Asia”. The new campaign "also features a heart containing some of the crucial elements of Taiwan, including food, culture, festive events and biodiversity.” (Shan, 2011)

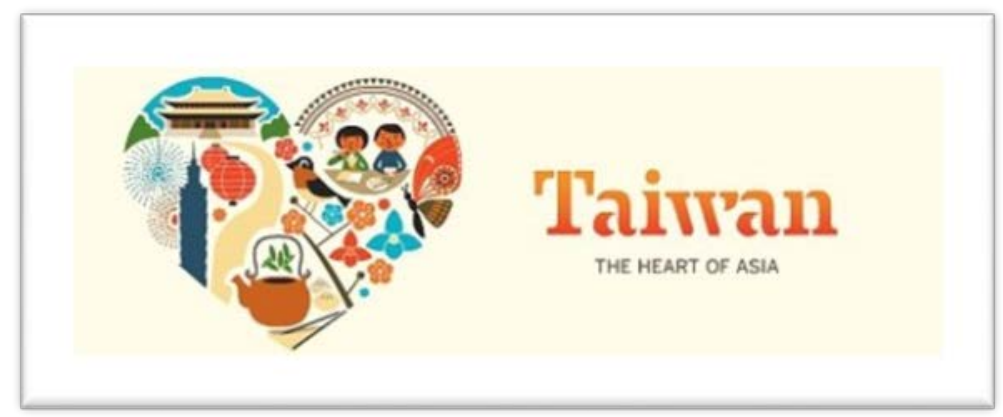

As the two examples suggest, all related marketing components should consistently reflect the brand promise and destination identity. In gastro-tourism destination identity encompasses 1) individual purveyor identities; 2) sub-groups or trails of purveyors, even if only loosely organized; and 3) the overall regional or country destination identity. Successful gastro-tourism destinations cross-promote all three identities and address any potential disconnects. The figure 5 below symbolizes the co-dependent nature that will exist, particularly in emergent markets.

\section{Figure 5}

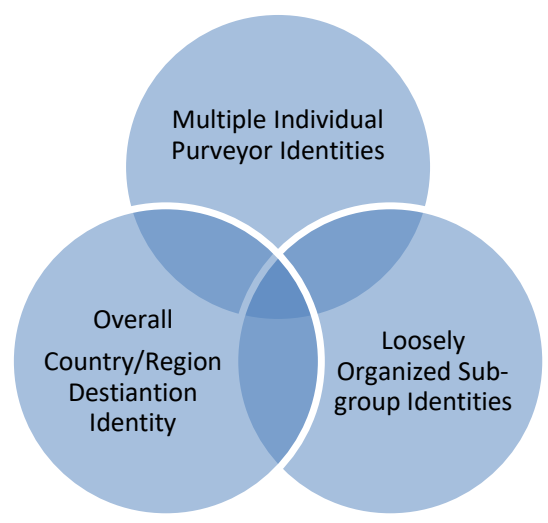

Market and Promote the gastro-destination 
In a study highlighting some of the differences between what is and what should be in a culinary tourism campaign, Harrington (2011) identified six key areas associated with culinary tourism success: 1) the strategy itself; 2) cooperation among stakeholders; 3) leadership issues; 4) culinary profile promotion; 5) communication of quality; 6) enhancing tourist perceptions. The first three areas (strategy, stakeholder cooperation and leadership) are important considerations for the purveyors of the gastro-events. The remaining three areas (culinary profile/brand identity, quality and tourist perceptions form the backbone of the marketing effort involved in gastro-tourism in emerging markets. Kay, (2003, p.64) advises that "in the early stages of the motivational process, marketing communication campaigns and activities, in particular, have an important role to play in converting positive attitudes and motives for attending cultural experiences into actual attendees.”

When developing a marketing plan, three items are paramount: 1) Purveyors, 2) Transportation, 3) Communication (figure 6).

\section{Figure 6. Marketing and Promotion Requirements.}

Purveyors
- Minimum of 6 memorable
sites/experiences
- Knowledgeable
enthusiastic hosts \& guides
- Creation of safety \&
cleanliness guidlelines
- Written /audio
descriptions of the
sites/experiences
- Clearly articulated brand
promises/expectatons
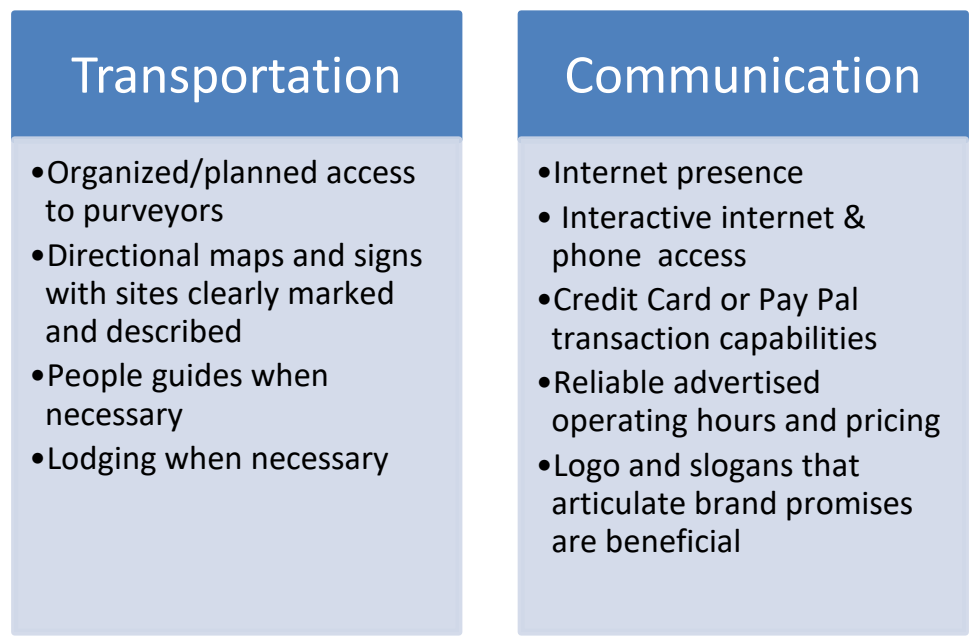

As discussed earlier, the transportation infrastructure and purveyor network must be able to accommodate the tourist demand generated by the communication programs.

\section{Evaluate}

A continuous evaluation cycle is essential for a gastro-tourism effort to take hold and to grow. It is necessary to constantly monitor tourist expectations, individual purveyor needs and gross economic and infrastructure demands of the region. By staying on top of tourist demands for transportation, health 
and safety, and purveyor satisfaction, the gastro-tourism effort can minimize potential risks and capitalize on existing and potential benefits (figure 7).

\section{Figure 7}

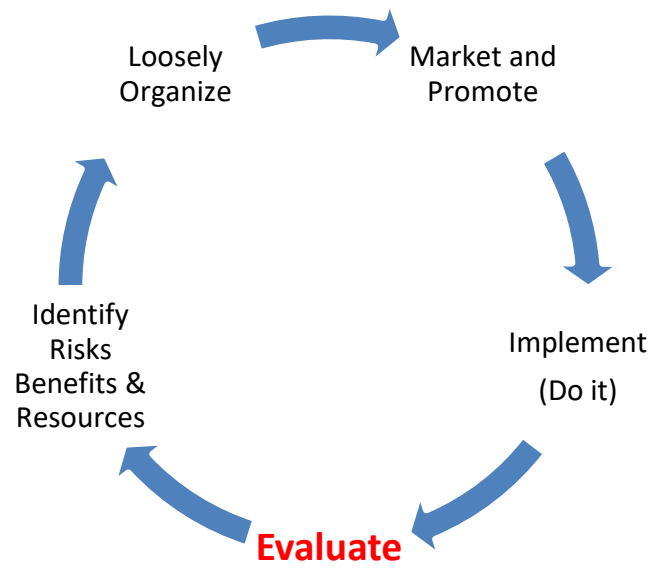

\section{Conclusion}

Although Destination Branding in this tourist segment may look very different from country to country or town to town, the critical components and clearly successful branding message concerning meaningful culinary experiences was clear. This preliminary subjective research also suggests that it is possible to ignite a profitable culinary tourism business with: 1) a spattering of homegrown resources and rich talent, 2) an organized and marketed façade or brand and 3) minimal adjustments to a few necessary, but considerably basic infrastructures such as transportation, health and safety. 


\section{References}

Aaker, D.A. and Joachimsthaler, E. (2000) Brand Leadership, The Free Press, New York.

Anholt, S, (2004). “Branding Places and Nations,” in Brands and Branding (The Economist Series)

Anholt, S. (2007). Competitive identity: the new brand management for nations, cities and regions. New York: Palgrave Macmillan.

Beard J.G. and M.G. Ragheb (1983). “Measuring Leisure Motivation”. Journal of Leisure Research. $3^{\text {rd }}$ Ed. Quarter, 219-228

Cai, L., (2002) “Cooperative Branding for Rural Destinations”, Annals of Tourism Research, Vol. 29, No. 3, pp.726-742

Caldwell, N., Freire, J., (2004), The Differences between Branding a Country, a Region and a City: applying the brand box model, Journal of Brand Management, Vol. 12, No. 1, pp.50-61

Curtis, J., (2001), Branding a State: the evolution of Brand Oregon, Journal of Vacation Marketing, Vol. 7, No.1, pp.75-81

Gaggiotti, H., Cheng, P. and Yunako, O., (2008), "City Brand Management (CBM): the case of Kazakhstan,” Place Branding and Policy Diplomacy, Vol. 4, No. 2, pp.115-123

Gilmore, F. (2002) A Country - can it be repositioned? Spain - the success story of country branding, BrandManagement, Vol. 9, No. 4-5, pp.281-293

Gnoth, J. (2002) Leveraging Expert Brands through a Tourism Destination Brand, Journal of Brand Management, Vol.9, No. 4-5, pp.262-280

Gordin, V. (2009). (In Russian). Features of the development of cultural tourism in St. Petersburg. In Titov, A. (Eds.), Features of the development of cultural tourism in St. Petersburg. Actual problems of development services:18-29. St. Petersburg: Publishing StPSUEF.

Hall, C. M., \& Mitchell, R. (2005). “Gastronomic tourism: Comparing food and wine tourism experiences”. In M. Novelli (Ed.), Niche tourism: Contemporary issues, trends and cases: 73-88. Oxford: Elsevier Butterworth- Heinemann.

Hall, CM, Sharples, L., Mitchell R., Macionis, N. \& Cambourne, B. (Eds.). (2003). Food tourism around the world: development, management and markets. Boston, MA:

Butterworth Heinemann.

Hankinson, G. (2004), Relational Network Brands: towards a conceptual model of place brands, Journal of Vacation Marketing, Vol. 10, No. 2, pp.109-121 
Hanna, S. and Rowley, J. (2010), "Towards a Strategic Place Brand Management Model,” Journal of Marketing Management, October

Henderson, J.C.(2009). “Food Tourism Reviewed”. British Food Journal, 111(4):317-326.

Hjalager, A-M. (2002). “A typology of gastronomy tourism.” In A-M Hjalager \& G. Richards (Eds.), Tourism and Gastronomy: 21-35. London: Routledge.

Hjalager, A-M. \& Richards, G. (ed). (2002). Tourism and Gastronomy. London:

Routledge.

Kavaratzis, M. (2004) From City Marketing to City Branding: toward a theoretical framework for developing city brands, Place Branding, Vol. 1, No. 1, pp.58-73

Kavaratzis, M. and Ashworth, G. (2005), "City Branding: an affective assertion of identity or a marketing trick,” Tijdschrift voor Economische en Sociale Geografie, Vol. 96, No. 5, pp.506-614

Kay , H.K.(2003), Selling Tourism, New York: Thomson Ltd.

Keller, K.L. (1993), “Conceptualizing, measuring, and managing customer-based brand equity”, Journal of Marketing, Vol. 57, No. January, pp. 1-22

Kim, Y.H., Goh, B.K. \& Yuan, J. (2010). A development of a multi-dimensional scale for measuring the motivation factors of food tourists as a food event: what does motivate people to travel? Journal of Quality Assurance in Hospitality and Tourism, 11(1), 56-71.

Kim, K.Y. and Jogaratnam, G. (2002) Travel motivations: A comparative study of Asian international and domestic American college students. Journal of Travel and Tourism Marketing, Vol. 13, No.4, pp.61-82

Kivela, J. and Crotts, R. (2006). Tourism and gastronomy: gastronomy's influence on how influence on haw tourists experience a destination. Journal of Hospitality and Tourism, 3(30), 354-377

Konecnik, M. (2002) "The image as a possible source of competitive advantage of the destination - The case of Slovenia”, Tourism Review, Vol. 57, No. 1-2, pp.6-12

Kozak, M. (2002) Comparative analysis of tourist motivations by nationality and destinations. Tourism Management, Vol.23, No.3, pp.221-232

Laws, E. (2002) Tourism Marketing: Service and Quality Management Perspectives, Continuum, London, New York, Stanley Thames

Lee, U. and Pearce, P.L. (2003). Travel career patterns: Further conceptual adjustment of travel career ladder. Paper presented at the Second Asia Pacific Forum for Graduate Students Research in Tourism, Busan, Korea; 2-4 October, 2003 
Lindstrom, M. (2005) “Broad sensory branding”, Journal of Product \& Brand Management, 14/2 pp.84-87

Long, Lucy M., (1998) ed. Culinary Tourism: Eating and Otherness. Special Issue of Southern Folklore 55/3 (1998).

Long, L.M. (Ed.) (2004), Culinary Tourism, The University Press of Kentucky, Lexington Kentucky. USA

Mannell, R.C. and Iso-Ahola, S.E. (1987). "Psychological nature of leisure and tourism experience.” Annals of Tourism Research, Vol. 14, No.3, pp.324-331

MIFAFF (2008) Ministry for food, Agriculture, Forestry, and Fisheries, About MIFAFF:Vision Last modified 2008. http://english.mifaff.go.kr/USR/WPGE0201/

Morgan, N., Pritchard, A. and Pride, R. (2002), Destination Branding: creating a unique destination proposition, Butterworth Heinemann

Morgan, N., Pritchard, A. and Pride, R. (2004), Destination Branding: creating a unique destination proposition, Butterworth Heinemann

Moscardo, G., A. M. Morrison, P.L. Pearce, C. Lang and J.T. O”Leary (1995). Understanding Vacation Destination Choice through Travel Motivation and Activities. Journal of Vacation Marketing, 2(2); 109-122.

Olins , W. (2003), Hull: pioneering city, case study”, Retrieved from www.wolffolins.com/files/Hull_0202News815000.pdf, accessed 09/15/2012

Papadopolos, N. and Heslop, L. (2002) "Country Equity and Country Branding: problems and prospects,” Journal of Brand Management, Vol.9, No. 4-5, pp.294-314

Parkerson, N. and Saunders, J (2005) "City Branding: can goods and services branding models be used to brand cities?”, Place Branding and Policy Diplomacy, Vol. 1, No. 3, pp.242-264

Pearce, P.L. (1993), “Fundamentals of tourist motivation”, in Pearce, D.G. and Butler, R.W. (Eds),Tourism Research: Critiques and Challenges, Routledge, London, pp. 113-34.

Pearce, P.L. and Lee, U. (2005). Developing the travel career approach to tourism motivation. Journal of Travel Research, Vol. 43, No.3, pp.226-237

Pearce, P. L., Morrison, A. M., \& Rutledge, J. L. (1998). "Motivation influence in tourism Demand”. In P. L. Pearce, A. M. Morrison \& J. L. Ruthledge (Eds.), Tourism: Bridges 
across continents. Sydney: McGraw-Hill.

Pike, S. (2005), “Tourism Destination Branding Complexity,” Journal of Product and Brand Management, Vol. 14, No. 4, pp.258-259

Pine, J. and Gilmore, J. (1999). The experience economy: work is theatre \& every business a stage. Boston: Harvard Business School press.

Prebensen, N.K. (2007) A Grammar of Motives for Understanding Individual Tourist Behavior, Doctor Dissertations. Retrieved Mar 10, 2012, 02:08AM from: http://hdl.handle.net/2330/1481

Quan, S. and Wang, N. (2004), "Toward a structural model of the tourist experience: an illustration from food experiences in tourism”, Tourism Management, Vol. 25, pp. 297-305.

Rao, V. (2001). "Celebrations as social investments: Festival expenditures, unit price variation and social status in rural India”. The Journal of Development Studies, 38(1), 71-97

Shan, S. (2011) Tourism Bureau launches logo, Taipai Times, 2/12/2011, p.2

Smith, S., and Xiao, H. (2008). "Culinary Tourism Supply Chains: A preliminary examination.” Journal of Travel Research, 46(3), 289-299.

Wolf, E. (2002). Culinary tourism: A tasty economic proposition. Retrieved from http://www.culinarytourism.org 